\title{
Upper Palaeolithic and Mesolithic human fossils from Moravia and Bohemia (Czech Republic): some new ${ }^{14} \mathrm{C}$ dates
}

\author{
Jiří A. Svoboda, Johannes van der Plicht \& VítĚzSlav KuŽelKa*
}

\begin{abstract}
New radiocarbon dates from four Moravian and Bohemian sites are presented and linked to previous work on the depositional contexts of human fossils at similar sites in the region. Whilst dates from Mladeč confirm its early Upper Palaeolithic age, the chronologies of the other three sites require revision.
\end{abstract}

Key-words: radiocarbon dating, Upper Palaeolithic, Mesolithic, Moravia, Bohemia

\section{Introduction}

Traditionally, the territories of Moravia and Bohemia (Czech Republic) are considered rich in human fossils from Upper Pleistocene and Early Holocene contexts. However, the fossil lists, as included in the available Catalogues and other reviews (Vlček 1971; Valoch 1996; Svoboda et al. 1996; Jelínek \& Orvanová 1999; Wolpoff 1999) are constantly being supplemented and modified by new discoveries both in the field (Matoušek 2000; Svoboda et al. 2000a) and in the collections (Trinkaus et al. 1999; 2000), by rediscovering old fossils believed to be lost (Svoboda 2001b; Drozdová 2001), and by new dates improving both the chronologies and the archaeological contexts (Pettitt \& Trinkaus 2000).

We review here ${ }^{14} \mathrm{C}$ dates for the region, obtained from materials such as bone, charcoal and calcite. The bone samples provide direct dates, whereas charcoal and calcite yield associated dates. The dates are all shown in TABLES $1 \& 2$. The samples received the standard ${ }^{14} \mathrm{C}$ pretreatment to remove contaminants. Large samples were measured by the conventional method (GrN, Groningen; ISGS, Illinois), and small samples (mg size) by AMS (GrA, Groningen; OxA, Oxford). For ages beyond 20,000 , there are inconsistencies in published 'calibration' records and thus in absolute chronology, so that we use the ${ }^{14} \mathrm{C}$ chronology in this text. The measurements are all corrected for isotopic factionation, and are reported in BP (Mook \& Streurman 1983).
In addition to a previous paper on the depositional context of the human fossils from Mladeč and Koněprusy-Zlatý kůň (Svoboda 2000), we focus in this paper on new ${ }^{14} \mathrm{C}$ dates, obtained recently from four Moravian and Bohemian sites: Mladeč, Koněprusy-Zlatý kůň, Svitávka and Obř́íství, and discuss them in the chronological framework of the human fossils from Moravia and Bohemia. It appears that the Mladeč dates confirm the expectations very well, whereas dates from the other three sites make a revision and reclassification of the contexts of these human fossils necessary.

\section{New dates from the four Czech sites Mladeč I (Central Moravia)}

Sites I-II from Mladeč are characterized by a multi-floor karstic system in the Tresín Hill. It is penetrated by vertical fissures and chimneys, where more than 100 specimens of anatomically modern human fossils were found at various locations between 1881 and 1922 (Szombathy 1925; Bayer 1925; Smyčka 1922; Skutil 1938; Jelínek 1983; Oliva 1993; Wolpoff 1999). The aim of our present project was the reconstruction of the depositional context, as it was before removal of sedimentary cave fillings, by combining the early reports with evidence from sediment relicts still present in the cave, using a Surfer programme graphic presentation (Svoboda 2000). It appeared that all human fossils were related to debris cones accumulated under the chimneys, the largest being

* Svoboda,Institute of Archaeology, ASCR, Department of Paleolithic and Paleoethnology, Brno-Dolní Věstonice, Czech Republic. svoboda@iabrno.cz van der Plicht, Groningen University, Center for Isotope Research, Nijenborgh 4, 9747 AG Groningen, Netherlands. Kuželka, National Museum, Department of Anthropology, Václavské nám. 68, 12000 Prague, Czech Republic.

Received 15 October 2001, accepted 31 January 2002, revised 14 April 2002

ANTIQUITY 76 (2002): 957-62 
the so-called Chimney of the Dead at site I. The majority of the cone deposits are of Middle Pleistocene age; the dating of the anatomically modern human fossils found in their uppermost parts was based primarily on the presence of the Mladeč points, i.e. bone projectiles considered culturally diagnostic for the Early Upper Palaeolithic in general and the Aurignacian in particular (Albrecht et al. 1972; Svoboda 2001a). Dating the human bones directly was unsuccessful thus far. Through the courtesy of Drs Szilvassy, Wolpoff and Frayer, a human rib fragment from the main cave, chamber $D$, locus $d$, associated with Mladeč crania 1,2 and 4 , was submitted to the Oxford Accelerator for dating in 1987 by C. Stringer (pers. comm.). Unfortunately it contained insufficient collagen to produce a radiocarbon date (R. Housley pers. comm.).

Our dating efforts concentrated on site I, Szombathy's find-spot 'a' in the so-called Dome of the Dead. The graphic reconstruction shows that before removal of the sediments this spot lay at the foot of the large debris cone under the Chimney of the Dead (Svoboda 2000: figure 5). According to Szombathy (1925; Tafel 2, Abb. 2), his trench, $3 \mathrm{~m}$ deep, was sealed at the top by a solid calcite cover (layer 1); just below it followed the deposits with Upper Pleistocene human and faunal remains (layer 2), whereas the majority of underlying deposits (layers 3-7) were sterile. Today, several generations of calcite layers are still visible on the cave wall adjacent to the find-spot, sealing the top of this sequence. In 1994, an attempt was made to date two calcite layers by means of U-series isotopes, but the samples appeared to be contaminated by clay (A. Latham pers. comm.).

Two other samples, both from the top calcite layers and $5 \mathrm{~cm}$ apart, were collected recently and dated by ${ }^{14} \mathrm{C}$. The results obtained from the carbonate are $34,160(+520-490)$ BP for the upper sample (GrN-26333) and 34,930 $(+520-490)$ BP for the lower sample (GrN-26334). Based on $\delta^{13}$ values, the reservoir ages are $c$. 800 years (sample 1) and c. 1200 years (sample 2). There is one basic assumption here: the travertine should have been formed in more or less streaming, recent (at the time of formation) water, and not in e.g. fossil age water.

In addition, a fragment of animal bone from the Olomouc museum collection was submitted for ${ }^{14} \mathrm{C}$ dating. Unfortunately, no collagen could be extracted from this bone.
According to Szombathy's (1925) description of the locus ' $a$ ' at Mladeč I (Dome of the Dead), the human fossils were located directly below the surface calcite layer, and a similar position was reported by Smyčka (1922) from another location of the same debris cone. In fact, portions of the calcite are still visible on some of the fossils preserved in the Vienna Natural History Museum. Since the interval between our two samples documents a rapid formation of the series of calcite layers, we may conclude that the deposition of human bodies was either more or less contemporaneous or slightly earlier. We conclude that our two ${ }^{14} \mathrm{C}$ dates of $34,000-35,000 \mathrm{BP}$ provide the minimal ages of the fossils; a direct date from the human bone is still needed for confirmation.

\section{Koněprusy-Zlatý kuํ (Bohemian Karst)}

The karstic system of the Zlatý kůň Hill resembles that at Mladeč, being another multi-floor cave site, with skeletal remains of a female individual found in one of the deep cavities (the Prošek Hall) on the surface of a debris cone under a vertical chimney (Prošek 1952; Vlček 1957; Kuželka 1997; Svoboda 2000: figures 2$3)$. Whereas at Mladeč the deposition of human bodies seems to be a repeatedly practiced act, Koněprusy shows a single event. At both sites, human bodies were deposited during terminal stages of the accumulation of the debris cones. This analogy, together with the associated fauna, led researchers to date the time of deposition at both sites to the Early Upper Palaeolithic. Supporting evidence for Koněprusy was scarce: stratigraphically, the human remains were deposited on or just below the surface, the associated lithic artefacts were culturally undiagnostic and the presumed bone projectile fragment (Mladeč-type) later appeared to be just a fragmented bone. In addition, the glacial fauna from the upper layers of the debris cone might be older than the human fossils.

For dating, VK selected a fragment of $4 \times 2$ $\mathrm{mm}$ size, most probably from the cranial base of the buried individual.

Methodically, it is crucial how the date of $12,870 \pm 70$ BP (GrA-13696), obtained from this human bone, changes our perspective in the search for analogies. In fact, the parallels now turn from the distant Moravian cave to the local regional archaeological background. The region of the Bohemian karst has a predomi- 
nantly Magdalenian occupation. No significant Early Upper Palaeolithic site has been proved before in the vicinity. The nearby site of Hostim, which seems to be a kind of central living-site for the Bohemian Magdalenian, is dated to $12,420 \pm 470$ BP (Ly 1108). Another important Magdalenian living site, the Děravá Cave (undated), opens in marginal rock walls of the same Zlatý kưň Hill (Fridrich \& Sklenář 1976; Vencl 1995). In this perspective, the Koněprusy human fossil provides the first evidence of mortuary behaviour that may well be related to the Magdalenian settlement system of the Bohemian karst. However, we still propose to confirm this single date by additional dating. In particular, as at Mladeč, we propose to date the calcite layers which have originally sealed the sediments and which, nowadays, are still attached at the walls of the Prošek Hall.

The analogy with the Early Upper Paleolithic site of Mladeč would suggest that deposition of human bodies into deep karstic cavities was a type of mortuary behaviour with a longer duration and transcultural significance. This is further confirmed by the recent discovery of Mesolithic human skeletal remains in a smaller karstic fissure on top of the Bacín Hill (Bohemian karst), dated to $9500 \mathrm{BP}$ (Matoušek 2000).

\section{Svitávka (Central Moravia)}

Skeletal fragments of a female individual were discovered at Svitávka during geological surveying in 1962 (Smolíková \& Ložek 1963). The find was dated to the Upper Palaeolithic (Klíma 1963; Vlček 1971) because of its location in a palaeosol stratified in the loess section, and its association with several lithic artefacts, charcoal and fauna, and because of morphological similarities of the facial bones with the find Brno 3. The latter, however, is lost today and quite doubtful as an Upper Palaeolithic specimen as well.

With the more detailed geological evidence known today, it appears that the type of chernozem palaeosols in which the find was presumably located developed earlier during the last glaciation (between late OIS stage 5 and stage 3). Their last formation, at Stránská skála, is dated to $c .30,000$ BP (Svoboda \& Bar-Yosef in press). This stratigraphic position would exclude the Svitávka female from the Gravettian group, where it has usually been placed, and make it older. At the same time, several an- thropologists pointed to the surface fossilization, including its whitish colouration, which is different from the more fossilized Upper Palaeolithic specimens. All this information raised considerable doubts as to the age of the find.

For dating, VK selected a fragment of the cranial vault, $10 \times 5 \mathrm{~mm}$ in size. The result, $1180 \pm 50$ BP (GrA-13711), confirms the earlier doubts about the Pleistocene age of the fossil. Most probably, it is an early medieval pit burial, hollowed as deep as the level of the palaeosol and later filled with loess. More such cases are known and documented from other geological sections where the outlines of such pits in the loess are invisible.

\section{Obříství (Central Bohemia)}

On a sandy dune at the Labe river plain, Prošek discovered four child burials in 1949, with no archaeological context. They were dated as probably Mesolithic for several reasons: firstly, the burial pits were covered by a well-developed Holocene soil attributed to the Atlantic period; secondly, there was a suspicious lack of associated artefacts; and thirdly, Mesolithic occupation was documented at other sites in the region (Vlček 1956; 1971). However, Neolithic occupation is also present. The date obtained from burial 4, a fragment of mesial part of a rib, $20 \mathrm{~mm}$ long (4650 $\pm 50 \mathrm{BP}$, GrA13710), points nevertheless to the later, Neolithic or Eneolithic age, which is still consistent with the geological situation. The lack of associated artefacts, as a negative argument, seems weak to support any dating. Naturally, since the new date only refers to one of the four burials, and Mesolithic sites are found in the area, additional dating may be useful to confirm this first result.

\section{Discussion: radiocarbon chronology for Upper Paleolithic and Mesolithic human fossils from the Czech Republic}

The Mladeč I (locus 'a') fossils belong to the earliest anatomically modern humans in Europe, being at least 34,000 years old. The dates compare well with the published dates from Vogelherd (Stetten, Germany), another Central European human fossil site with at least three individuals, dated by ${ }^{14} \mathrm{C}$ between 30,700 and 31,900 BP (H-series; Churchill \& Smith 2000; Conard 2001). Whereas at Mladeč the Aurig- 
site/fossil no.

lab no.

GrN-26333

Mladeč I-1

Mladeč I-2

Koněprusy

Svitávka

Pavlov-Northwest

DV II triple burial

DV II triple burial

DV II triple burial

DV II male burial

DV II male burial

DV II male burial

DV II fossil 33

DV II fossils $36,39,49$

DV II fossil 47

DV II fossils 51-52

DV I fossil 35

Brno 2

GrN-26334
GrA-13696
GrA-13711
GrN-20391
GrN-14831
ISGS-1616
ISGS-1617
GrN-15276
GrN-15277
ISGS-1744
GrN-15324
GrN-21122
GrN-15279
GrN-21123
OxA-8292
OxA-8293

material

calcite

calcite

human bone

human bone

charcoal, exc. 1957

associated charcoal

associated charcoal

associated charcoal

associated charcoal

associated hearth

associated charcoal

associated hearth

associated hearth

associated hearth

associated hearth

human femur

human rib context

${ }^{14} \mathrm{C}$ age (BP)

Aurignacian

Aurignacian

Magdalenian

to be cancelled

Pavlovian

Pavlovian

Pavlovian

Pavlovian

Pavlovian

Pavlovian

Pavlovian

Pavlovian

Pavlovian

Pavlovian

Pavlovian

Gravettian

Willendorf-Kostenkian
$34,160+520 /-490$

$34,930+520 /-490$

$12,870 \pm 70$

$1180 \pm 50$

$26,170 \pm 450$

$26,640 \pm 110$

$24,000 \pm 900$

$24,970 \pm 920$

$25,570 \pm 280$

$25,740 \pm 210$

$26,390 \pm 270$

$27,070 \pm 170$

$26,970 \pm 200$

$26,920 \pm 250$

$26,390 \pm 190$

$22,840 \pm 200$

$23,680 \pm 200$

TABLE $1 .{ }^{14} \mathrm{C}$ dates for human fossils of the Upper Palaeolithic. DV: Dolní Věstonice.

$\begin{array}{ll}\text { site } & \text { lab no. } \\ \text { Obříství 4 } & \text { GrA-13710 } \\ \text { Nízká Lešnice } & \text { GrN-24210 } \\ \text { Vysoká Lešnice } & \text { GrN-24217 } \\ \text { Sídelník } & \text { GrA-11456 } \\ \text { Pod zubem } & \text { GrN-23333 } \\ \text { Pod zubem } & \text { GrN-23332 } \\ \text { Bacín } & \text { OxA-9271 }\end{array}$

material

human bone

underlying charcoal

associated charcoal

associated hearth

associated charcoal

associated charcoal

human femur context

to be cancelled

Mesolithic

Mesolithic

Mesolithic

Mesolithic

Mesolithic

Mesolithic
${ }^{14} \mathrm{C}$ age (BP)

$4650 \pm 50$
$10,160 \pm 190$
$7930 \pm 160$
$7120 \pm 80$
$6580 \pm 50$
$6790 \pm 70$
$9490 \pm 65$

TABLE 2. The Obřiství ${ }^{14} \mathrm{C}$ date in context with other dates for Mesolithic human fossils and fragments.

nacian classification is based on the bone projectiles only (which may appear in other Early Upper Palaeolithic contexts as well), the site of Vogelherd provided a rich and complex Aurignacian evidence, including typical lithic industry and art. However, the dating of Mladeč I human fossils make them contemporary not only with the series of ${ }^{14} \mathrm{C}$ dates from other Aurignacian settlements along the upper and middle Danube (South Germany, Lower Austria), but also with the latest Bohunician occupations at Stránská skála, Moravia (Svoboda \& Bar-Yosef in press). It should be recalled that this time-period saw a mosaic-like pattern of persisting 'transitional' cultural entities at the same time as the expanding Aurignacian.

On the other hand, certain Central European sites, presumably Early Upper Palaeolithic, should now be excluded from this chronological context. The first was Velika Pečina in Croatia, dated to around $5000 \mathrm{BP}$ (Smith et al. 1999), now fol- lowed by Zlatý kůn̆ at Koněprusy, dated to 12,900 BP and reclassified as Magdalenian, and Svitávka, dated to $1200 \mathrm{BP}$ and classified most probably as an early medieval burial.

The majority of the Upper Palaeolithic human fossils from the Czech Republic are from the Gravettian context. Based on a large series of new ${ }^{14} \mathrm{C}$ dates and a few stratigraphic superpositions, this complex is now being separated into earlier (Pavlovian, 30-25,000) and later (Willendorf-Kostenkian, 25-20,000) stages. In general, most of the Gravettian dates from the four major settlements (Pavlov I, Dolní Věstonice I-II and Předmostí I) correspond with the Evolved Pavlovian interval, i.e., between 27,000 and 25,000 BP (van der Plicht 1997; Svoboda et al. 2000b). The site of Dolní Věstonice II in particular, well-structured spatially and chronologically and also relatively rich in human fossils, yields insight into this chronology (Trinkaus et al. 2000; Svoboda 2001c). 
Focussing on dates obtained from the Groningen Laboratory, from charcoal associated with buried human skeletons (DV 13-15, DV 16), from the central hearths of the same settlement units as the human fossils, and on the dates obtained directly from human bones (TABLE 1), it appears that a few smaller human fragments such as DV $33,36,39,47$, and 49 fall to the 27,000 year horizon (specific at the site of Dolní Věstonice II), whereas the majority of finds, such as the triple burial, the male burial and others, follow with the subsequent Evolved Pavlovian stage $(27-25,000)$. The same is generally true for Dolní Věstonice I, Pavlov I and Předmostí I. The only later burial, corresponding with the Willendorf-Kostenkian stage of the Gravettian, is Brno 2 (23,700 years, Pettitt \& Trinkaus 2000). This later burial is specific because of its location outside the typically Pavlovian regions and settlements, and because of the unusual richness of the grave goods. Another later date $(22,800)$ obtained directly from the femur DV 35 from the site of Dolní Věstonice I is probably contaminated, since most of the other dates from the DV I settlement correspond with the Evolved Pavlovian stage (Trinkaus et al. 1999).

\section{References}

ALBRECHT, G., J. HAHN \& W. TORKE. 1972. Merkmalanalyse von Geschoßspitzen des mittleren Jungpleistozäns in Mittelund Osteuropa. Stuttgart: W. Kohllhammer. Archaeologia Venatoria 2.

BAYER, J. 1925. Die ältere Steinzeit in den Sudetenländern, Sudeta 1: 21-120.

CONARD, N. 2001. Chronostratigraphy of the Aurignacian in the Swabian Jura as a test of the Danube corridor and Kulturpumpe models, in UISPP, XIVe Congres, Pre-Actes: 139-40. Liège: Université de Liège.

DROZDOVÁ, E. 2001: The human mandible from Předmostí, Archeologické rozhledy 53: 450--56.

Churchill, S.E. \& F.H. SMITH. 2000: Makers of the Early Aurignacian of Europe, Yearbook of Physical Anthropology 43: 61-11.5.

FRIDRIGH, J. \& K. SKLENÁŘ. 1976: Die paläolithische und mesolithische Höhlenbesiedlung des Böhmischen Karstes. Prague: Národní muzeum.

JELÍNEK, J. 1983: The Mladeč finds and their evolutionary importance, Anthropologie/Brno 21: 57-64.

JELínEK, J. \& E. ORVANOVÁ. 1999. Czech and Slovak Republics, in R. Orban (ed.), Hominid remains: an up-date = Anthropologie et préhistoire, supplément 9: 1-118.

KLÍMA, B. 1963. Die Entdeckung eines pleistozänen Menschen bei Svitávka, Přehled vízkumů 1962: 2-3.

KUŽELKA, V. 1997. The postcranial skeletal remains of Pleistocene man from Zlatý kůň near Koněprusy (Bohemia), Anthropologie/Brno 35: 247-9.

MATOUŠEK, V. 2000. Bacín: $9490 \pm 65$ BP a $428 \pm 37$ BP. Nová ${ }^{14} \mathrm{C}$ data $\mathrm{z}$ Ceského krasu, Archeologie ve středních Cechách 4: $15-30$.

MOOK, W.G. \& H.J. StreuRman. 1983. Physical and chemical aspects of radiocarbon dating, in First International Sym-
The new date of 12,900 for the human skeletal remains from the deep cavity of KoněprusyZlatý kủn fits well into the series of Magdalenian dates which range between 13,000 and 12,500 , both in Bohemia (Hostim) and Moravia (Pekárna, Kolíbky; cf. Valoch 1996; Svoboda et al. 1996).

The Mesolithic, a period traditionally neglected by Czech archaeological research, is only now receiving a chronological framework. However, it is not yet established nor published in full. Whereas the old Obřiství find appears to be Post-Mesolithic based on our new ${ }^{14} \mathrm{C}$ date, new human fossil sites are being discovered and ${ }^{14} \mathrm{C}$-dated recently (TABLE 2). This affects, among others, the directly dated Mesolithic human bones from a karstic fissure at Bacín Hill in the Bohemian karst (Matoušek 2000), and a series of small human fragments from the Mesolithic excavation project in sandstone rock-shelters of North Bohemia, dated by means of charcoal obtained from the same levels and from the related hearths (Svoboda et al. 2000a).

Acknowledgement. We thank Professor Emanuel Vlček, D.Sc, for consultation on the palaeoanthropological aspects of this paper.

posium on ${ }^{14} \mathrm{C}$ and Archaeology, Groningen, $1989=P A C T$ publications 8: 31-55.

Oliva, M. 1993. Le contexte archéologique des restes humains dans la grotte de Mladeč, in UISPP, XIIe Congres, Volume 2: 207-16. Bratislava: Institut d'Archéologie.

PETTITT, P.B. \& E. TRINKAUS. 2000. Direct radiocarbon dating of the Brno 2 Gravettian human remains, Anthropologie/ Brno 38: $149-50$

PRošEK, F. 1952. Výzkum jeskyně Zlatého koně u Koněprus, Čskoslovenský kras 5: 161-79.

SkUTIL, J. 1938. Pravěké nálezy v Mladči u Litovle na Moravě. Litovel: Krajinská musejní společnost.

SMTth, F.H., E. Trinkaus, P.B. PetTtTt, I. Karavanić \& M. Paunović. 1999. Direct radiocarbon dates for Vindija $G_{1}$ and Velika Pečina Late Pleistocene hominid remains, Proceedings of the National Academy of Sciences 96: 12,281-6.

SMOLíKOVÁ, L. \& V. LOŽEK, 1963. Interglaciál a nález pleistocénního člověka u Svitávky, Časopis pro mineralogii a geologii 8: 189-97.

SMYČKA, J. 1922. Nálezy diluviálního člověka v Mladči u Litovle na Moravĕ, Obzor prehistorický 1: 111-20.

SVOBODA, J. 2000. The depositional context of the Early Upper Paleolithic human fossils from the Konepprusy (Zlatý kunn) and Mladeč Caves, Czech Republic, Journal of Human Evolution 38: 523-36.

2001a. Mladec and other caves in the Middle Danube region: early modern humans, late Neandertals, and projectiles, in Les premiers hommes modernes de la Péninsule Ibérique. Actes du colloque de la Commission VIII de l'UISPP: 45-60. Lisbon: IPA.

2001b. Analysis of the large hunter's settlements: excavation at Předmostí in 1992, Archeologické rozhledy 53 431-43. 
2001c. Analysis of the large hunter's settlements: spatial structure and chronology of the site Dolní Věstonice IIIIa, Památky archeologické 92: 74-97.

SVOBODA, J., V. LOŽEK \& E. VLČEK. 1996. Hunters between East and West. The Paleolithic of Moravia. New York (NY): Plenum.

SvobodA, J., L. JarošovÁ \& E. DRozdová. 2000a. The North Bohemian Mesolithic revisited: the excavation seasons 1998-1999, Anthropologie/Brno 38: 291-305.

Svoboda, J., B. Klíma, L. Jarošová \& P. ŠKRDLA. 2000b. The Gravettian in Moravia: climate, behaviour and technological complexity, in W. Roebroeks, M. Mussi, J. Svoboda \& K. Fennema (ed.), Hunters of the Golden Age. The mid Upper Palaeolithic of Eurasia, 30,000-20,000 BP: 197217. Leiden: Leiden University Press.

SVOBODA, J. \& O. BAR-Yosef (ed.). In press. Stránská skála. Early Upper Paleolithic occupations in the Brno Basin, Moravia. Cambridge (MA): Harvard University Press.

SzombaTHY, J. 1925. Die diluvialen Menschenreste aus der FürstJohanns-Höhle bei Lautsch in Mähren, Eiszeit 2/1: 1-34, 73-95.

Trinkaus, E., J. JELíñeK \& P.B. PettitT. 1999. Human remains from the Moravian Gravettian: The Dolní Věstonice 35 femoral diaphysis, Anthropologie/Brno 37: 167-75.

Trinkaus, E., J. SvOBODA, D.L. WEST, V. SLÁdEK, S.W. Hillson, E. DROZDOVÁ \& M. FIŠÁKOVÁ. 2000. Human remains from the Moravian Gravettian: Morphology and taphonomy of isolated elements from the Dolní Vèstonice II site, Journal of Archaeological Science 27: 1115-32.

VALOCH, K. 1996. Le paléolithique en Tchéquie et en Slovaquie. Grenoble: J. Millen.

VAN DER PliCHT, H. 1997. The radiocarbon dating, in Pavlov INorthwest $=$ The Dolní Věstonice Studies 4: 427-36. Brno: Institute of Archaeology.

VencL, S. 1995. Hostim. The Magdalenian in Bohemia. Prague: Institute of Archaeology.

VLČEK, E. 1956. Staroholocenní kostrové pohřby z Obříství u Mělníka (Early Holocene skeleton burials from Obř́ství near Mělník), Anthropozoikum 5: 233-85.

1957. Pleistocénní çlověk z jeskyně na Zlatém koni u Koněprus, Anthropozoikum 6: 283-311.

1971. Czechoslovakia, in K.P. Oakley, B.G. Campbell \& T.I. Molleson (ed.), Catalogue of fossil hominids: 47-64. London: British Museum (National History).

WOLPOFF, M.H. 1999. Paleoanthropology. 2nd edition. Boston (MA): McGraw-Hill.

\title{
Birch-bark tar at Neolithic Makriyalos, Greece
}

\section{DushKa Urem-Kotsou, Ben Stern, Carl Heron \& Kostas Kotsakis*}

\author{
The authors discuss the first evidence for the use of birch-bark tar on Late Neolithic pottery \\ from Greece. This appears to have been used for two different purposes, to seal a fracture and \\ to line the interior walls. The authors also discuss other possible uses.
}

Key-words: Makriyalos, Greece, Late Neolithic, birch-bark tar, gas chromatography-mass spectrometry

\section{Introduction}

The potential for organic analysis of Neolithic pottery from Greece is largely unexplored. The results of a pilot study conducted on vessels from the Late Neolithic settlement at Makriyalos, northem Greece are reported in part here. Gas chromatography-mass spectrometry (GC-MS) is used to study the lipid composition of 19 vessels representing the range of main vessel types. The lipids from visible residue and ceramic extracts of three of these vessels show the presence of molecular markers consistent with birch-bark tar. These results are the first evidence in Greece both for its use and for the use of natural products to affect the performance characteristics of pottery vessels.

\section{The site}

The site at Makriyalos is situated in the coastal area of Pieria, Northern Greece (FIGURE 1), less than $2 \mathrm{~km}$ from the sea. Fifteen $\mathrm{km}$ to the west lie the Pieria Mountains with Mt Olympus, the highest mountain in Greece, on the southern side. The settlement is located on the gentle slopes of a natural low hill. Two ravines pass near the site to the northeast and southwest. The prehistoric settlement covers about $\mathbf{5 0}$ ha and is one of the largest non-tell sites in prehistoric Macedonia. Two main phases of occupation, Makriyalos I and II, both dated to the Late Neolithic period, are clearly distinguished (Pappa \& Besios 1999).

\section{Samples}

All 19 vessels analysed for organic residues come from Makriyalos I which is dated to the beginning of the Late Neolithic period (c. 5400-4900 BC; Pappa \& Besios 1999). Samples of three of

\footnotetext{
* Urem-Kotsou \& Kotsakis, Department of Archaeology, Aristotle University, 54006 Thessaloniki, Greece. Stern \& Heron, Department of Archaeological Sciences, University of Bradford, Richmond Road, Bradford BD7 $1 \mathrm{DP}$, England.
}

Received 11 October 2001, accepted 26 February 2002, revised 15 August 2002

ANTIQUITY 76 (2002) 962-7 